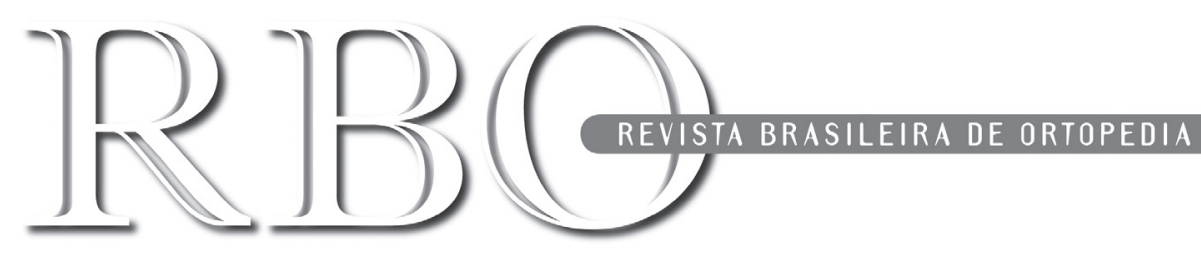

\title{
Editorial
}

\section{Uma nova era para a RBO}

O momento atual das publicações científicas nos obriga a uma reflexão.

Temos pelo menos dois tipos de publicação:

- uma publicação feita com sentido prático para ser lida por seus pares e desta forma divulgar o conhecimento e os autores no meio em que vivem e trabalham - são as revistas de leitura;

- uma publicação feita segundo padrões internacionais, selecionada para indexação em uma base de dados e lida via internet por pesquisadores que porventura venham a se interessar pelo tema em qualquer parte do mundo

- são as revistas de pesquisa.

A primeira é uma revista que será recebida ou comprada pelo leitor e fará parte de seu acervo para ser consultada quando necessário; a segunda estará na internet e será pesquisada nas bases de dados e talvez nunca seja vista na sua forma física.

As duas têm a sua importância e a sua utilidade, de acordo com a razão da consulta. Os redatores das revistas de leitura, por exemplo, consultarão as revistas de pesquisa para a produção dos seus trabalhos.

Os dois tipos não se excluem nem competem entre si, são apenas opções que devem ser consideradas; o redator deve, ao montar o seu texto, escolher uma das duas opções e desenvolver o seu trabalho com um objetivo claro.

Os órgãos que fiscalizam o ensino superior valorizam as revistas de pesquisa e os serviços universitários, em atenção a esta valorização, sugerem a seus membros que priorizem as suas publicações em revistas de pesquisa; por esta razão tivemos durante um período uma fuga de importantes publicações da RBO, para revistas de pesquisa muito pouco consultadas por ortopedistas. Houve um prejuízo para os ortopedistas brasileiros, que não tiveram acesso a importantes trabalhos nacionais e para os redatores, que não tiveram os seus recentes estudos divulgados no seu meio profissional.

A RBO era por tradição uma revista de leitura, para ser consultada e guardada; é distribuída gratuitamente na casa de 10.000 leitores. A sua indexação na Scielo transformou-a também em uma revista de pesquisa, tornando os seus trabalhos conhecidos no meio ortopédico nacional e disponíveis ao pesquisador.

Esta qualificação de revista indexada nos coloca em uma nova era, que exigirá a manutenção e a melhoria da qualidade do conteúdo, porém com a vantagem de disponibilizarmos todo este esforço aos nossos quase 10.000 sócios.

Para mim é uma honra entrar nesta nova era como o quarto editor-chefe da RBO na sua história de 42 anos, sucedendo Marcio Ibrahim de Carvalho, Donato D'Angelo e Carlos Giesta.

Espero ser iluminado com o pioneirismo de Marcio Ibrahim, que iniciou o TEOT e a RBO estruturada, a simpatia e o sentido de instituição de Donato D'Angelo, que editou a RBO por 27 anos, e a classe e o rigor de Carlos Giesta, que permitiu a indexação da revista na Scielo.

Assumo esta missão com a consciência de estar assumindo o cargo mais importante de minha vida acadêmica e a maior responsabilidade de minha longa carreira na SBOT.

Imagino uma RBO prática e acessível ao ortopedista brasileiro, com a qualidade de uma revista internacional. Para tal conto com a colaboração de todos os ortopedistas que ora são leitores, ora redatores da RBO.

Gilberto Luis Camanho Editor chefe da RBO 